\title{
Anti-psychiatric Therapeutic Interchanges: A Narrative Reviews
}

Yousef Ahmed Alomi', BSc. Pharm, MSc. Clin Pharm, BCPS, BCNSP, DiBA, CDE, Critical Care Clinical Pharmacists, TPN Clinical Pharmacist, Freelancer Business Planner, Content Editor and Data Analyst, Riyadh, Saudi Arabia. Faiz Abdullah. Bahadig, R.Ph, Informatics Pharmacist, Pharmaceutical Care Department, King Abdul-Aziz Medical, City-WR-Jeddah, Ministry of National Guard, Saudi Arabia.

\section{Correspondence:}

Dr. Yousef Ahmed Alomi, BSc. Pharm, MSc. Clin Pharm, BCPS, BCNSP, DiBA, CDE, Critical care clinical pharmacists, TPN clinical pharmacist, Freelancer Business Planner, Content Editor and Data Analyst. P.O.BOX 100, Riyadh 11392, Riyadh, Saudi Arabia

Phone no: +966504417712

E-mail:yalomi@gmail.com
Received: 19-8-2019;

Accepted: 1-12-2019

Copyright: (c) the author(s), publisher and licensee International Journal of Pharmacology and Clinical Sciences. This is an open-access article distributed under the terms of the Creative Commons Attribution Non-Commercial License, which permits unrestricted non-commercial use, distribution, and reproduction in any medium, provided the original work is properly cited.

This is an open access article distributed under the terms of the Creative Commons Attribution-NonCommercial-ShareAlike 4.0 License

Access this article online

\begin{tabular}{|c|c|}
\hline & www.ijpcs.net \\
\hline & DOI: \\
\hline
\end{tabular}

\section{ABSTRACT}

Objective: To review the anti-psychiatric therapeutic interchanges drug therapy. Methods: It is an extensive search, or fifty databases comprised the following through the Saudi Digital Library (SDL) searching engine. It included the various types of studies (meta-analysis, randomized controlled studies and observational studies) in the English language with human study only for the update May 2017. The search in terms of therapeutic interchange, medication, therapy and type of disease or medication base on therapeutics class of anti-psychiatric. The medication list and switch from one drug to alternative based on the literature found the search that has included comparative safety, efficacy and cost of the type of medication for each disease and national or international evidence-based guidelines. Results: The total number of studies after an extensive search with a specific term search was 487 studies. Of those, there were 107 repeated studies, and 380 studies included for future assessment. After assessment, there were 20 studies discussed the therapeutic interchange of antiPsychiatry. Of those 20 studies, three studies included for evaluation. Conclusion: Anti-psychiatric therapeutic interchange is seldom finding in the kinds of literature. Few observational studies discussed this matter. Further studies claim to standardized Anti-psychiatric therapeutic interchange in practice.

Key words: Anti-psychiatric, Therapeutic Interchanges, Drug Therapy, Literature, Review.

\section{INTRODUCTION}

The management of psychiatric illness had various difficulties. For instance, the response rate to drug therapy, patient's non-compliance and related factors. Besides, switching from one medication to another. ${ }^{1-3}$ The switching drug therapy from one to another might had serious drug-related adviser events and drug-drug interactions if not considered the properties and advantages of the medication. ${ }^{1-3}$ As a result, if there is any lack of anti-psychotic medications, there will be critical problems during switching therapy. The appropriate solution is a therapeutic interchange that's switching the medications from one to an equal drug with efficacy, indicators and safety. Various international studies had been done on the antipsychotic therapeutic interchange. ${ }^{4-6}$ However, the local studies about antipsychotic therapeutic interchange not existed and there are some physician order drug therapy with mentioned alternative drug therapy. The aim of the current study is to reveal the review of the antipsychotic therapeutic interchange system in the Kingdom of Saudi Arabia.

\section{MATERIALS AND METHODS}

It is extensive search or fifty databases included the following through Saudi Digital Library (SDL) searching engine; Willy online library, Web of Science, Springer link, Taylor and Francis, Social Science Journal via ProQuest, Science Journal via ProQuest, Scopus, Scifinder, Science Direct, Sage Journal, Royal Society of Medicine, Royal Society of Chemistry, Psychology Journals via ProQuest. Pharmaceutical news index via
ProQuest, patient education via MD consult, Drug via $\mathrm{MD}$ consult, Oxford Journals via Oxford University, Ovid Journals, Nursing and Allied Health Sources via ProQuest, Nature Publisher group, Medline index via ProQuest, Medline complete via EBSCO, Medical Evidence Matter via ProQuest, IGI InfoSci Journals, Health Management via ProQuest, Health and Medical complete via ProQuest. Global Health Database-CABI, Family Health via ProQuest, Eric via ProQuest and EBSCO, Emerald, Dynamed via EBSCO, Directory of Open Access Journal (DOAJ), Current Content via Web of Knowledge, Dentistry and Oral Science via EBSCO, Clinical Key -Nursing, Clinical Key- Physician, CINAHL via EBSCO, Central via ProQuest, CBCA via ProQuest, Canadian Science Publishing. Cambridge Journals via Cambridge University, Britannica Academic, BMJ Journals, BMJ Clinical Evidence via BMJ Best Practice, BMJ Best Practice, Biology Journals via ProQuest, ACM Digital Library, Academic Search Ultimate via EBSCO, Cochrane Library PubMed. In addition to Google, Scholar searched alone without SDL. It encompassed a variety of studies (meta-analysis, randomized controlled studies and observational studies) in the English language with human study only for an update in May 2017. The search in terms of therapeutic interchange and medication, therapy and type of disease or medication base on therapeutics class. The medication list and switch from one drug to alternative based on the literature found the search, that has included comparative safety, efficacy and cost 
of the type of medication for each disease and national or international evidence-based guidelines. ${ }^{1-3,7,8}$ The anti-psychiatric medication interchange list included drug name, general dosing and frequency. All settings of patient care services inpatient or ambulatory care or community services oral medication included. All dosage form medication will be included in the search. All medications should include the Ministry of Health formulary. The location of studies included Saudi Arabia as top propriety if hasn't existed Gulf or Middle East counties included, if not found overall counties included. If not existed the table recommended from authors experiences.

\section{RESULTS}

The total number of studies after an extensive search with a specific term search was 487 studies. Of those, there were 107 repeated studies, and 380 studies included for future assessment. After assessment, there were 20 studies discussed the therapeutic interchange of antiPsychiatry. Of those 20 studies, three studies included for evaluation (figure 1). Other studies did not fit with the criteria. One study for antidepressants interchange, one study for generic olanzapine interchange, one study about fluoxetine and sertraline interchange. All studies had been done in the USA within the period 1975-2015. The number of patients does not exceed more than 25 patients; That is mean the number of patients was few and the number of antibiotics interchange was few. The mainstream of studies were non-randomized controlled studies; most of the studies were observational studies. The cost-saving not documented within all discussed studies (Table 1).

\section{DISCUSSION}

The combination field of therapeutic interchange and anti-psychiatric medications had various difficulties. With extensive, comprehensive research with only 17 studies had vital words. However, three studies fit with methodology regulation. After physically searched, very studies might be exploited in the discussion. There are no randomized clinical trials or meta-analysis studies to discuss the therapeutic interchange of anti-psychotic medications. Maybe single medications to alternative interchange study. One old study discussed therapeutic interchange of a class of antidepressant which need to be updated. Another method was used to interchange therapy based on therapeutic management guidelines. The first line therapy must be used and if it not existed the second-line drug therapy should be used as an alternative therapy. Besides, there was some suggestion to used therapeutic interchange by used of among medications salts. The drug used interchangeably to their salts and trance Versa. The authors and his team suggest the therapeutic interchange medications list recommended of therapeutic drove from update literature and one mental hospital (Table 2). Of the first medications not available, the doctor can use the second one interchangeably. Despite there are no studies to validate it. However, it best indication that's we have to implement the international therapeutic interchange for antipsychotic medications. ${ }^{9-13}$ All medications demand further future studies to evaluate the evidence. Therapeutic interchange one of the best tools used in the hospital and community pharmacy that's to keep the medications available over 24 hours and seven days per week.

\section{CONCLUSION}

Therapeutic interchange services are highly needed by all medical and surgical services, including psychiatric services. Few studies conducted for therapeutic interchange in psychiatric. However, comparative studies used all alternative methods for interchange therapy. The method was used in international and local therapeutic management guidelines. Further studies are highly demanded to validate psychiatric therapeutic interchange to prevent drug misadventures, drug-related problems and shortage stock of antipsychotic medications. The healthcare institutions appropriately use the suggested list to implement antipsychotic therapeutic interchange at healthcare organizations in the Kingdom of Saudi Arabia.

\section{ACKNOWLEDGMENT}

None.

\section{CONFLICT OF INTEREST}

None.

\section{ABBREVIATIONS}

MOH: Ministry of Health; KSA: Kingdom of Saudi Arabia; USA: United States of America, TI: Therapeutic Interchange; SDL: Saudi Digital Library

\section{ORCID ID}

Yousef Ahmed Alomi https://orcid.org/00000003-1381-628X
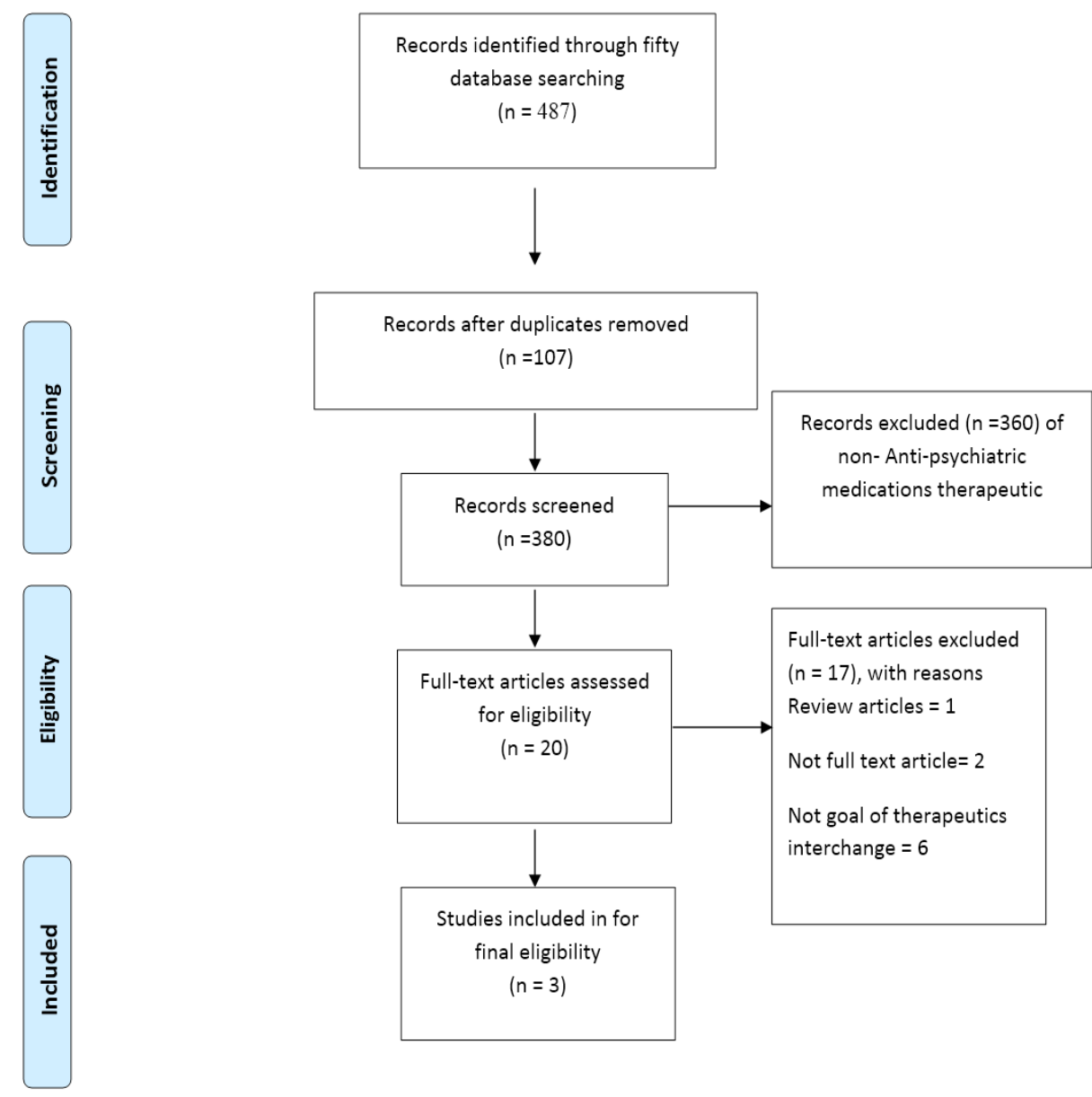

Figure 1: Results of searching the literature. 


\begin{tabular}{|c|c|c|c|c|c|c|c|c|}
\hline No. & Author & $\begin{array}{c}\begin{array}{c}\text { Year } \\
\text { of } \\
\text { publication }\end{array} \\
\end{array}$ & Country & $\begin{array}{c}\text { No. of } \\
\text { participants }\end{array}$ & Duration & $\begin{array}{l}\text { Study } \\
\text { design }\end{array}$ & Outcome & Comments \\
\hline 1. & Stock A, et al. (1) & 1994 & USA & NA & 3 years & $\begin{array}{l}\text { The interchange from } \\
\text { Fluoxetin } 20 \mathrm{mg} \text { to } \\
\text { Sertlraline } 50 \mathrm{mg}\end{array}$ & $\begin{array}{l}\text { The results should } \\
\text { the impact of the } \\
\text { experiences of } \\
\text { the therapeutic } \\
\text { interchange was } \\
\text { cost-saving at one } \\
\text { hospital. }\end{array}$ & $\begin{array}{l}\text { The study was } \\
\text { done in one } \\
\text { year. The net } \\
\text { cost saving not } \\
\text { documented }\end{array}$ \\
\hline 2. & Extein I, et al. (2) & 1975 & USA & NA & NA & $\begin{array}{l}\text { Two-way inter-change } \\
\text { observation study of } \\
\text { antipsychotics and } \\
\text { antidepressant drug }\end{array}$ & $\begin{array}{l}\text { There were some } \\
\text { differences ins MOC }\end{array}$ & NA \\
\hline
\end{tabular}

Table 2: Suggested Antipsychiatry Therapeutic Interchange Medication list.

\begin{tabular}{|c|c|c|c|c|c|c|c|}
\hline \multirow[t]{2}{*}{ No. } & \multicolumn{3}{|c|}{ Ordered Drug or Interchange Drug(4)(5)(6)(7) } & \multicolumn{3}{|c|}{ Ordered Drug or Interchange Drug(4)(5)(6)(7) } & \multirow{2}{*}{$\begin{array}{l}\text { Indication, } \\
\text { Registration(8) }\end{array}$} \\
\hline & Regular Days & Doses/ Day & Frequency Per day & Regular Days & Doses/Day & Frequency Per day & \\
\hline 1. & $\begin{array}{l}\text { Citalopram OR } \\
\text { Escitalopram }\end{array}$ & $\begin{array}{l}10-20 \mathrm{mg} \\
10-20 \mathrm{mg}\end{array}$ & $\begin{array}{l}\text { In } 1 \text { dose } \\
\text { In } 1 \text { dose }\end{array}$ & $\begin{array}{l}\text { Citalopram OR } \\
\text { Escitalopram }\end{array}$ & $\begin{array}{l}10-20 \mathrm{mg} \\
10-20 \mathrm{mg}\end{array}$ & $\begin{array}{l}\text { In } 1 \text { dose } \\
\text { In } 1 \text { dose }\end{array}$ & RSFDA , MOHDF \\
\hline 2. & $\begin{array}{l}\text { Venlafaxine ER OR } \\
\text { Venlafaxine }\end{array}$ & $\begin{array}{l}37.5-75 \mathrm{mg} \\
75 \mathrm{mg}\end{array}$ & $\begin{array}{c}\text { In } 1 \text { dose } \\
\text { Divided in 2-3 doses }\end{array}$ & $\begin{array}{l}\text { Venlafaxine ER OR } \\
\text { Venlafaxine }\end{array}$ & $\begin{array}{c}37.5-75 \mathrm{mg} \\
75 \mathrm{mg}\end{array}$ & $\begin{array}{c}\text { In } 1 \text { dose } \\
\text { Divided in 2-3 doses }\end{array}$ & RSFDA, MOHDF \\
\hline 3. & $\begin{array}{l}\text { Venlafaxine ER OR } \\
\text { Desvenlafaxine }\end{array}$ & $\begin{array}{c}37.5-75 \mathrm{mg} \\
50 \mathrm{mg}\end{array}$ & $\begin{array}{l}\text { In } 1 \text { dose } \\
\text { In } 1 \text { dose }\end{array}$ & $\begin{array}{l}\text { Venlafaxine ER OR } \\
\text { Desvenlafaxine }\end{array}$ & $\begin{array}{c}37.5-75 \mathrm{mg} \\
50 \mathrm{mg}\end{array}$ & $\begin{array}{l}\text { In } 1 \text { dose } \\
\text { In } 1 \text { dose }\end{array}$ & RSFDA, MOHDF \\
\hline 4. & $\begin{array}{l}\text { Risperidone OR } \\
\text { Paliperidone }\end{array}$ & $\begin{array}{c}4-8 \mathrm{mg} \\
3 \text { to } 12 \mathrm{mg}\end{array}$ & $\begin{array}{l}\text { In } 1 \text { dose } \\
\text { In } 1 \text { dose }\end{array}$ & $\begin{array}{l}\text { Risperidone OR } \\
\text { Paliperidone }\end{array}$ & $\begin{array}{c}4-8 \mathrm{mg} \\
3 \text { to } 12 \mathrm{mg}\end{array}$ & $\begin{array}{l}\text { In } 1 \text { dose } \\
\text { In } 1 \text { dose }\end{array}$ & RSFDA, MOHDF \\
\hline 5. & $\begin{array}{l}\text { Na Valproate OR } \\
\text { Divalproex }\end{array}$ & $\begin{array}{c}750 \mathrm{mg} \\
750-1000 \mathrm{mg}\end{array}$ & $\begin{array}{c}\text { Target trough } \\
\text { plasma level was } 50 \\
\text { to } 125 \mathrm{mcg} / \mathrm{mL}(347\end{array}$ & $\begin{array}{l}\text { Na Valproate } \\
\text { Divalproex }\end{array}$ & $\begin{array}{l}750 \mathrm{mg} \\
\begin{array}{c}750-1000 \\
\mathrm{mg}\end{array}\end{array}$ & $\begin{array}{l}\text { Target trough plasma } \\
\text { level was } 50 \text { to } 125 \\
\mathrm{mcg} / \mathrm{mL}(347\end{array}$ & RSFDA, MOHDF \\
\hline 6. & $\begin{array}{l}\text { Amisulpride OR } \\
\text { Olanzapine }\end{array}$ & $\begin{array}{l}400-800 \mathrm{mg} \\
5-20 \mathrm{mg}\end{array}$ & $\begin{array}{c}\text { Divided in } 2 \text { divided } \\
\text { doses } \\
\text { In } 1 \text { dose }\end{array}$ & $\begin{array}{l}\text { Amisulpride OR } \\
\text { Olanzapine }\end{array}$ & $\begin{array}{l}400-800 \mathrm{mg} \\
5-20 \mathrm{mg}\end{array}$ & $\begin{array}{c}\text { Divided in } 2 \text { divided } \\
\text { doses } \\
\text { In } 1 \text { dose }\end{array}$ & $\begin{array}{c}\text { General } \\
\text { Schizophrenia } \\
\text { RSFDA, MOHDF }\end{array}$ \\
\hline 7. & $\begin{array}{l}\text { Risperidone OR } \\
\text { Paliperidone OR } \\
\text { Quetiapine }\end{array}$ & $\begin{array}{c}4-8 \mathrm{mg} \\
3 \text { to } 12 \mathrm{mg} \\
150-750 \mathrm{mg}\end{array}$ & $\begin{array}{c}\text { In } 1 \text { dose } \\
\text { In } 1 \text { dose } \\
\text { In } 2-3 \text { divided doses }\end{array}$ & $\begin{array}{l}\text { Risperidone OR } \\
\text { Paliperidone OR } \\
\text { Quetiapine }\end{array}$ & $\begin{array}{c}4-8 \mathrm{mg} \\
3 \text { to } 12 \mathrm{mg} \\
150-750 \mathrm{mg}\end{array}$ & $\begin{array}{c}\text { In } 1 \text { dose } \\
\text { In } 1 \text { dose } \\
\text { In } 2-3 \text { divided doses }\end{array}$ & $\begin{array}{c}\text { General } \\
\text { Schizophrenia } \\
\text { RSFDA, MOHDF }\end{array}$ \\
\hline 8. & $\begin{array}{l}\text { Aripiprazole OR } \\
\text { Paliperidone }\end{array}$ & $\begin{array}{l}10-15 \mathrm{mg} \\
3-12 \mathrm{mg}\end{array}$ & $\begin{array}{l}\text { In } 1 \text { dose } \\
\text { In } 1 \text { dose }\end{array}$ & $\begin{array}{l}\text { Aripiprazole OR } \\
\text { Paliperidone }\end{array}$ & $\begin{array}{l}10-15 \mathrm{mg} \\
3 \text { to } 12 \mathrm{mg}\end{array}$ & $\begin{array}{l}\text { In } 1 \text { dose } \\
\text { In } 1 \text { dose }\end{array}$ & $\begin{array}{l}\text { Schizophrenia with } \\
\text { QTC prolongation } \\
\text { RSFDA, MOHDF }\end{array}$ \\
\hline
\end{tabular}




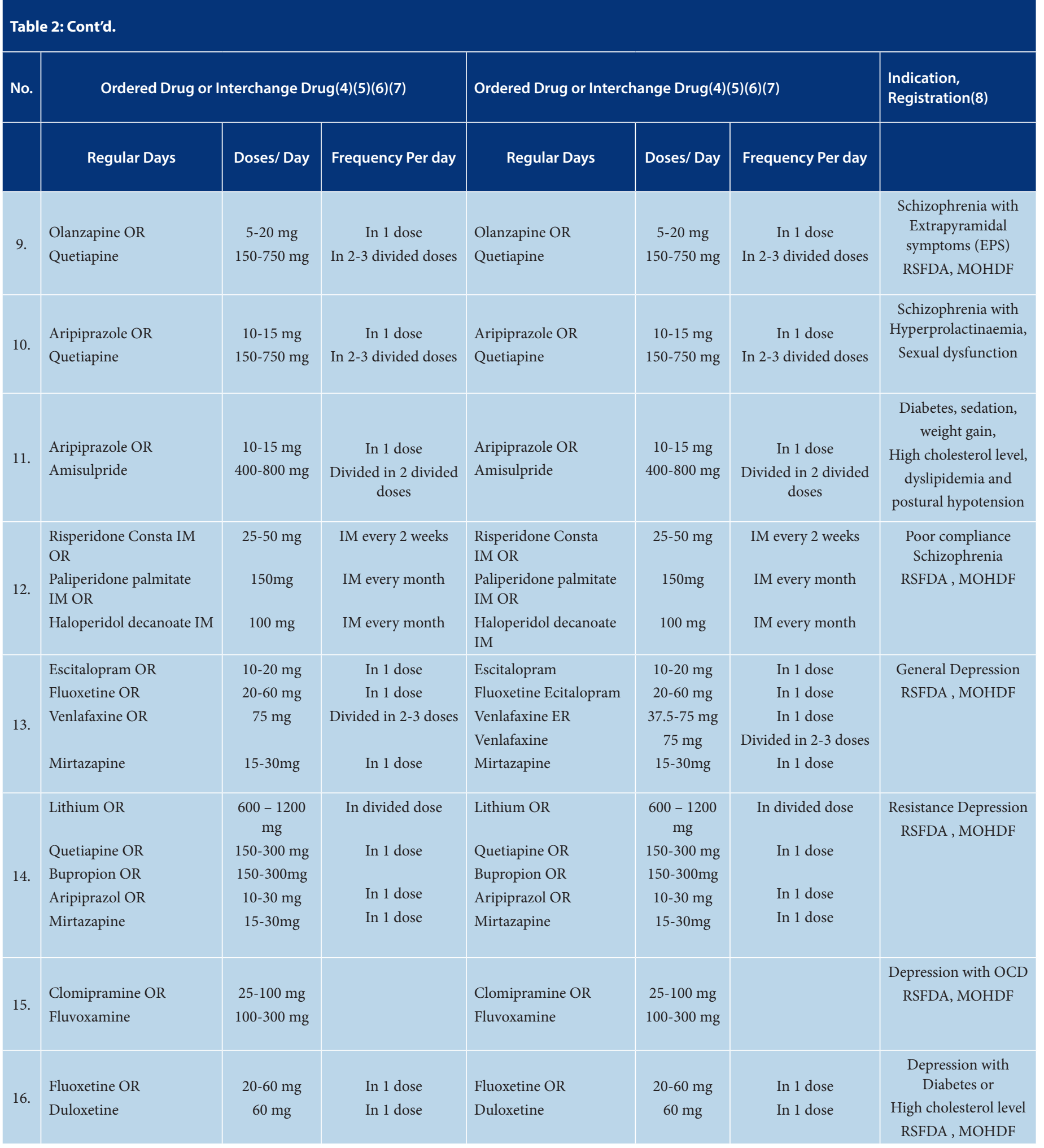

Continued... 


\begin{tabular}{|c|c|c|c|c|c|c|c|}
\hline \multirow[t]{2}{*}{ No. } & \multicolumn{3}{|c|}{ Ordered Drug or Interchange Drug(4)(5)(6)(7) } & \multicolumn{3}{|c|}{ Ordered Drug or Interchange Drug(4)(5)(6)(7) } & \multirow[t]{2}{*}{$\begin{array}{l}\text { Indication, } \\
\text { Registration(8) }\end{array}$} \\
\hline & Regular Days & Doses/ Day & Frequency Per day & Regular Days & Doses/ Day & Frequency Per day & \\
\hline 18. & $\begin{array}{l}\text { Escitalopram OR } \\
\text { Mirtazapine }\end{array}$ & $\begin{array}{l}10-20 \mathrm{mg} \\
15-30 \mathrm{mg}\end{array}$ & $\begin{array}{l}\text { In } 1 \text { dose } \\
\text { In } 1 \text { dose }\end{array}$ & $\begin{array}{l}\text { Escitalopram OR } \\
\text { Mirtazapine }\end{array}$ & $\begin{array}{l}10-20 \mathrm{mg} \\
15-30 \mathrm{mg}\end{array}$ & $\begin{array}{l}\text { In } 1 \text { dose } \\
\text { In } 1 \text { dose }\end{array}$ & $\begin{array}{l}\text { Depression with } \\
\text { Stroke } \\
\text { RSFDA, MOHDF }\end{array}$ \\
\hline 20. & $\begin{array}{l}\text { Aripiprazole OR } \\
\text { Olanzapin }\end{array}$ & $\begin{array}{l}10-15 \mathrm{mg} \\
5-20 \mathrm{mg}\end{array}$ & $\begin{array}{l}\text { In } 1 \text { dose } \\
\text { In } 1 \text { dose }\end{array}$ & $\begin{array}{l}\text { Aripiprazole OR } \\
\text { Olanzapin }\end{array}$ & $\begin{array}{l}10-15 \mathrm{mg} \\
5-20 \mathrm{mg}\end{array}$ & $\begin{array}{l}\text { In } 1 \text { dose } \\
\text { In } 1 \text { dose }\end{array}$ & $\begin{array}{l}\text { Acute mania or } \\
\text { hypomania } \\
\text { (Add to mood } \\
\text { stabilizer) } \\
\text { RSFDA, MOHDF }\end{array}$ \\
\hline 21. & $\begin{array}{l}\text { Risperidone OR } \\
\text { Quetiapine }\end{array}$ & $\begin{array}{c}2-8 \mathrm{mg} \\
100-800 \mathrm{mg}\end{array}$ & $\begin{array}{c}\text { In } 1 \text { dose } \\
\text { In } 2-3 \text { divided doses }\end{array}$ & $\begin{array}{l}\text { Risperidone OR } \\
\text { Quetiapine }\end{array}$ & $\begin{array}{c}2-8 \mathrm{mg} \\
100-800 \mathrm{mg}\end{array}$ & $\begin{array}{c}\text { In } 1 \text { dose } \\
\text { In 2-3 divided doses }\end{array}$ & $\begin{array}{l}\text { Acute mania or } \\
\text { hypomania } \\
\text { (Add to mood } \\
\text { stabilizer) } \\
\text { RSFDA, MOHDF }\end{array}$ \\
\hline 23. & $\begin{array}{l}\text { Aripiprazole OR } \\
\text { Lamotrigine OR } \\
\text { Na Valproate }\end{array}$ & $\begin{array}{c}10-15 \mathrm{mg} \\
100-200 \mathrm{mg} \\
750 \mathrm{mg}\end{array}$ & $\begin{array}{c}\text { In } 1 \text { dose } \\
\text { In } 1 \text { dose } \\
\text { Target trough } \\
\text { plasma level was } 50 \\
\text { to } 125 \mathrm{mcg} / \mathrm{mL}(347\end{array}$ & $\begin{array}{l}\text { Aripiprazole OR } \\
\text { Lamotrigine OR } \\
\text { Na Valproate }\end{array}$ & $\begin{array}{c}10-15 \mathrm{mg} \\
100-200 \mathrm{mg} \\
750 \mathrm{mg}\end{array}$ & $\begin{array}{c}\text { In } 1 \text { dose } \\
\text { In } 1 \text { dose } \\
\text { Target trough plasma } \\
\text { level was } 50 \text { to } 125 \\
\mathrm{mcg} / \mathrm{mL}(347\end{array}$ & $\begin{array}{c}\text { Bipolar disorder } \\
\text { with chronic diseases } \\
\text { Diabetes or } \\
\text { High cholesterol level } \\
\text { and Cardiovascular } \\
\text { disease }\end{array}$ \\
\hline
\end{tabular}

Note: The prescriber should adjust the dose after interchange according to the patient condition

RSFDA: The Drug had been registered in Saudi Food and Drug Authority, MOHDF: The Drug is Ministry of Health Drug Formulary

\section{REFERENCES}

1. AlomiYA, Alsolami N, Alqahtani N, etal. Depression management physician order: New initiatives at the Mental hospital of ministry of health in Saudi Arabia. J Pharm Pract Community Med. 2018;4(2):126-7.

2. Alomi YA, Alsolami N, Alqahtani N, et al. Schizophrenia treatment physician order: New initiatives at the Mental hospital of ministry of health in Saudi Arabia. Int J Pharm Heal Sci. 2018;1(1):1-5.

3. Alomi YA, Alsolami N, Alqahtani N, et al. Bipolar disorder management physician order: New initiatives at the Mental hospital of ministry of health in Saudi Arabia. J Pharm Pract Community Med. 2018;4(2):126-7.

4. Stock AJ, Kofoed L. Therapeutic interchange of fluoxetine and sertraline: Experience in the clinical setting. Am J Hosp Pharm. 1994;51(18):2279-81.

5. Extein I, Bowers MB. The pharmacologic meaning of successful antipsychotic-antidepressant combinations. Compr Psychiatry. 1975;16(5):427-34.

6. Italiano D, Bruno A, Santoro V, et al. Generic olanzapine substitution in patients with schizophrenia: Assessment of serum concentrations and therapeutic response after switching. Ther Drug Monit. 2015;37(6):827-30.

7. Royal Pharmaceutical Society. British National Formulary 76. Ah-See KW, et al. editors. British National Formulary. BMJ Group. 2019;1-1653.

8. Ministry of Health. Ministry of Health Formulary. Health Ministry of Health. 2012.

9. Mills EJ, Gardner D, Thorlund K, et al. A users' guide to understanding therapeutic substitutions J Clin Epidemiol. 2014;67(3):305-13.

10. Gray T, Bertch K, Galt K, et al. Guidelines for therapeutic interchange - 2004. Pharmacotherapy. 2005;25:1666-80.

11. Wall DS, Abel SR. Therapeutic-interchange algorithm for multiple drug classes. Am J Heal Pharm. 1996;53(11):1295-6.

12. Holmes DR, Becker JA, Granger CB, et al. ACCF/ AHA 2011 Health Policy Statement on Therapeutic Interchange and Substitution. Circulation. 2011;124(11):1290-310.

13. Compendium AMAP, Vol HP, et al. AMA policy on drug formularies and therapeutic interchange in inpatient and ambulatory patient care settings. Am J Hosp Pharm. 1994;51(14):1808-10. 